\title{
KOMPARASI DETERMINAN PEMBIAYAAN PADA BANK MANDIRI DAN BANK SYARIAH MANDIRI
}

\author{
Lantip Susilowati ${ }^{\bowtie}$, Nita Sistiani \\ Universitas Islam Negeri Sayyid Ali Rahmatullah Tulungagung, Indonesia \\ lantip_susilowati@yahoo.co.id, nitasistiani2008@gmail.com \\ https://doi.org/10.46367/jps.v2i2.379 \\ Received: Aug 15, 2021 Revised: Sep 17, 2021 Accepted: Sep 24, 2021 Published: Oct 14, 2021
}

\begin{abstract}
The purpose of this research is to show the differences in financing between Bank Mandiri and Bank Syariah Mandiri; the effect of the inflation rate on financing; the influence of the BI-7 day repo rate on financing; the influence of the number of third party funds on financing; the effect of the statutory reserve requirement on financing. This research uses a quantitative approach with associative and comparative types of research. The sampling technique used was the purposive sampling method. The test uses a hypothesis test and an independent sample test to compare the financial performance of the two banks. The results showed that the inflation rate, BI-7 day repo rate, and the minimum reserve requirement had no effect on financing at Bank Mandiri and Bank Syariah Mandiri. While thirdparty funds partially have a positive and significant effect on financing at Bank Mandiri and Bank Syariah Mandiri. There is a significant difference between financing between Bank Mandiri and Bank Syariah Mandiri. This research can provide input for Islamic banking, especially Bank Mandiri and Bank Syariah Mandiri, in determining profit-sharing financing policies.
\end{abstract}

Keywords: Inflation, BI-7 Day Repo Rate, Third-Party Funds, Statutory Reserve Requirement, Financing.

\begin{abstract}
ABSTRAK
Tujuan penelitian ini adalah menunjukkan perbedaan pembiayaan Bank Mandiri dengan Bank Syariah Mandiri; pengaruh tingkat inflasi terhadap pembiayaan; pengaruh BI-7 day repo rate terhadap pembiayaan; pengaruh jumlah dana pihak ketiga terhadap pembiayaan; pengaruh giro wajib minimum terhadap pembiayaan. Penelitan ini menggunakan pendekatan kuantitatif dengan jenis penelitian assosiatif dan komparatif. Teknik pengambilan sampel menggunakan metode purposive sampling. Pengujian menggunakan uji hipotesis dan independent sample test untuk membandingkan kinerja keuangan kedua bank tersebut. Hasil penelitian menunjukkan bahwa tingkat inflasi, BI-7 day repo rate dan giro wajib minimum tidak berpengaruh terhadap pembiayaan pada Bank Mandiri dan Bank Syariah Mandiri. Sedangkan dana pihak ketiga secara parsial berpengaruh positif dan signifikan terhadap pembiayaan pada Bank Mandiri dan Bank Syariah Mandiri. Terdapat perbedaan yang signifikan antara pembiayaan antara Bank Mandiri dan Bank Syariah Mandiri. Penelitian ini dapat memberikan masukan
\end{abstract}


bagi pihak perbankan syariah, khususnya Bank Mandiri dan Bank Syariah Mandiri dalam menentukan kebijakan pembiayaan bagi hasil.

Kata Kunci: Inflasi, BI-7 Day Repo Rate, Dana Pihak Ketiga, Giro Wajib Minimum, Pembiayaan.

\section{PENDAHULUAN}

Indonesia memiliki dua sistem perbankan yaitu bank konvensional dan bank syariah. Munculnya undang-undang nomor 10 tahun 1998 tentang perbankan, memberikan dasar bagi lembaga-lembaga keuangan konvensional untuk bisa membuka cabang unit usaha perbankan yang menggunakan basis syariah dalam pengoperasiannya. Kehadiran bank syariah ini nantinya bertujuan untuk menghindarkan operasional bank dari sistem bunga dan mengantinya dengan sistem bagi hasil yang sesuai prinsip Islam. Konsep dasar bank syariah didasarkan pada Al-Qur'an dan Hadits. Semua produk dan jasa yang diterbitkan dan ditawarkan tidak boleh bertolak belakang dengan isi Al-Qur'an dan Hadits Rasulullah SAW. Salah satu bank konvensional dan bank syariah di Indonesia adalah Bank Mandiri Tbk. dan Bank Syariah Mandiri Tbk.

Marimin and Romdhoni (2017) mengungkapkan bahwa Bank Mandiri merupakan salah satu bank BUMN Indonesia yang telah beroperasi selama 15 tahun. Bank Mandiri merupakan bank hasil upaya pemerintah merestrukturasi perbankan pasca krisis tahun 1998. Bank Mandiri merupakan salah satu bank milik pemerintah Republik Indonesia yang tergabung dalam Badan Usaha Milik Negara (BUMN). Saham sebesar 60\% dimiliki bank pemerintah Republik Indonesia dan 40\% sisanya dimiliki publik. Bank Mandiri mengklaim sebagai bank terbesar di Indonesia sekaligus sebagai bank BUMN terbesar di Indonesia berdasarkan total asetnya. Sedangkan Bank Syariah Mandiri sejak tahun 1999, sesungguhnya merupakan hikmah sekaligus berkah pasca krisis ekonomi dan moneter 1997-1998. Dari peristiwa itu Bank Syariah Mandiri hadir, tampil dan tumbuh sebagai bank yang mampu memadukan idealisme usaha dengan nilainilai rohani yang melandasi kegiatan operasionalnya.

Pada bank syariah, istilah kredit dikenal sebagai pembiayaaan, artinya kegiatan utang piutang yang digunakan oleh masyarakat dalam hal pemberian pinjaman kepada orang lain. Adapun istilah kredit atau pembiayaan lebih banyak digunakan oleh masyarakat pada transaksi perbankan dan pembelian yang tidak dibayar secara tunai. Namun pemaknaannya di masyarakat antara utang, kredit atau pembiayaan tidak jauh berbeda.

Sejauh ini penelitian mengenai faktor yang mempengaruhi pembiayaan terdapat beberapa aspek. Pertama, aspek inflasi sudah pernah diteliti oleh Dahlan (2014); Ali and Miftahurrohman (2016); Naufal, Fadilah, and Helliana (2017) dengan hasil yang beragam. Kedua, aspek BI Rate sudah pernah diteliti oleh Ali and Miftahurrohman (2016); Naufal, Fadilah, and Helliana (2017). Ketiga, aspek dana pihak ketiga sudah pernah diteliti oleh Ali and Miftahurrohman (2016); Anwar and Miqdad (2017); Bakti (2017); Fitri, Maulida, and Indrawati (2017); Naufal, Fadilah, and Helliana (2017); Husaeni (2017) dengan hasil yang beragam. Keempat, aspek giro wajib minimum sudah pernah diteliti oleh Fitri, Maulida, and Indrawati (2017). Berdasarkan penelitian yang sudah ada belum ditemukan 
pembahasan mengenai komparasi pengaruh tingkat inflasi, BI 7 day repo rate, dana pihak ketiga dan giro wajib minimum terhadap pembiayaan pada Bank Mandiri dan Bank Mandiri Syariah, sehingga ini bisa dijadikan gap penelitian dan perlu dilakukan penelitian lebih lanjut. Oleh sebab itu penelitian ini bertujuan untuk menunjukkan perbedaan pembiayaan Bank Mandiri dengan Bank Syariah Mandiri; pengaruh tingkat inflasi terhadap pembiayaan; pengaruh BI-7 day repo rate terhadap pembiayaan; pengaruh jumlah dana pihak ketiga terhadap pembiayaan; pengaruh giro wajib minimum terhadap pembiayaan.

\section{TELAAH LITERATUR}

\section{Asset and Liability Management (ALMA)}

Muhamad (2019, 197-198) mengungkapkan bahwa liability management sangat penting dilakukan karena kegiatan pencairan dana dan penyaluran dana dalam bentuk kredit harus dilakukan dalam rangka mengoptimalisasikan dana yang dihimpun untuk mendapatkan keuntungan bank. Assets and liabilities management (ALMA) merupakan suatu proses dari perencanaan, pengorgaisasian dan pengawasan yang berfungsi sebagai pengendalian aktiva dan pasiva secara terpadu yang saling berhubungan dalam usaha untuk mencapai keuntungan bank (Muhamad 2019, 197-198).

Adiwarman $(2013,472)$ menyampaikan bahwa dalam bank syariah, ALMA lebih bertumpu pada kualitas asset yang akan menentukan kemampuan bank untuk meningkatkan daya tariknya kepada nasabah untuk menginvestasikan dananya melalui bank tersebut yang berarti meningkatkan kualitas pengelolaan dananya. Kebijakan ALMA ini digunakan sebagai pengelolaan aset dan liabilitas bank syariah agar bank syariah dapat mengelola risiko yang mungkin timbul sehingga menghasilkan profit yang optimal pula. Jadi, dalam mengelola pembiayaan bank dipengaruhi oleh dua faktor yaitu eksternal dan internal. Faktor eksternal dipengaruhi tingkat inflasi, BI 7-Day Repo Rate. Sedangkan faktor internal dipengaruhi jumlah dana pihak ketiga dan giro wajib minimum, karena dari sisi lain, bank menerapkan akan menanggung risiko yang besar. Oleh karena, itu bank harus selalu memperhatikan pengelolaan aset dan liabilitasnya (Karim 2013, 472).

\section{Pembiayaan Bank Syariah}

Antonio $(2001,160)$ mengatakan bahwa pembiayaan adalah salah satu tugas yang harus ada pada sebuah bank, seperti menyediakan dana yang digunakan memenuhi kebutuhan pihak defisit unit. Sedangkan menurut Kasmir (2005, 92-93) dalam lembaga keuangan konvensional pembiayaan disebut dengan kredit yang diartikan sebagai kepercayaan. Pihak yang memberi kredit tersebut memberikan kepercayaan kepada pihak yang menerima kredit yang diberikan harus dikembalikan sesuai dengan perjanjian yang telah disepakati.

Ascarya $(2008,150)$ menyampaikan bahwa menyalurkan dana nasabah, produk-produk pembiayaan bank syariah dapat menggunakan 4 (empat) pola yang berbeda yaitu pola bagi hasil (syirkah), pola jual beli (ba'i), pola sewa (ijarah), dan pola pinjaman ( $q$ ard). Ada beberapa jenis pembiayaan yang dilakukan oleh bank konvensional, yaitu pembiayaan modal kerja syariah; pembiayaan investasi 
syariah; pembiayaan konsumtif syariah; pembiayaan sindikasi; pembiayaan letter of credit (L/C).

\section{Tingkat Inflasi}

Inflasi kenaikan harga secara umum dari barang/ komoditas dan jasa selama periode waktu tertentu (Campbell and Stanley 1990, 432). Menurut Karim (2004, 424) inflasi Islam tidak berbeda dengan Inflasi konvensional. Inflasi mempunyai sebuah gejala kenaikan harga barang yang bersifat umum dan terus menerus bahwa kenaikan harga ini berlangsung secara berkesinambungan (Karim 2004, 424). Dari dua pendapat para ahli tersebut diatas maka bisa dikatakan bahwa inflasi berpengaruh terhadap dunia perbankan sebagai salah satu institusi keuangan. bank sangat rentan dengan risiko inflasi terkait dengan mobilitas dananya (Yuniarti 2018, 128).

\section{BI 7- Day (Reverse) Repo Rate}

Bunga bank adalah balas jasa pada nasabah atas pembelian atau penjualan produk bank yang berdasarkan dengan prinsip konvesional (Kasmir 2016). BI Rate merupakan suku bunga dengan jangka waktu satu bulan sebagai sinyal dari kebijakan moneter yang diumumkan Bank Indonesia kepada publik secara periodik untuk jangka waktu tertentu. Suku bunga adalah presentase biaya pinjaman atau harga yang dibayarkan atas dana pinjaman tersebut (Siamat 2005). Puspopranoto $(2004$, 69) mengungkapkan bahwa BI rate atau suku bunga merupakan salah satu variabel yang selalu diamati dengan cermat karena dampaknya yang luas dalam perekonomian. Suku bunga juga mempengarhi terhadap keputusan ekonomi pengusaha atau pimpinan perusahaan untuk melakukan investasi baru atau perluasaan kapasitas.

Bank Indonesia telah melakukan penguatan kerangka operasi moneternya terhadap acuan tingkat suku bunga baru yaitu BI 7-day (reverse) repo rate yang mulai berlaku pada 19 Agustus 2018. Penguatan kerangka moneter ini untuk memperkuat efektivitas atas kebijakan dalam mencapai sasaran inflasi yang ditetapkan. BI 7-day (reverse) repo rate dapat secara cepat mempengaruhi pasar uang, dengan sifatnya yang transaksional atau diperdagangkan di pasar, dan mendorong pendalaman pasar keuangan (BI 2020).

\section{Dana Pihak Ketiga (DPK)}

Menurut Muhamad (2019, 119), dana pihak ketiga adalah dana dari masyarakat yang dititipkan pada bank, yang umumnya berupa giro, deposito, tabungan dan bentuk lainnya. Sedangkan menurut Kasmir $(2005,60)$ dana pihak ketiga adalah dana yang berasal dari masyarakat luas yang merupakan sumber dana terpenting bagi kegiatan operasional suatu bank dan merupakan ukuran keberhasilan bank jika mampu membiayai operasionalnya dari sumber dana ini. Demikian juga halnya pendapat Dahlan $(2012,124)$ yang menyatakan bahwa dana pihak ketiga sebagaimana pada lembaga bank secara umum, dalam penghimpunan dana bank syariah mempraktikkan produk tabungan, giro dan deposito.

\section{Giro Wajib Minimum (GWM)}

Saldo Minimum yang wajib dipelihara oleh bank-bank umum setiap saat atau perbandingan antara saldo giro bank yang wajib ditempatkan pada Bank 
Indonesia ditambah cadangan minimum yang wajib dipelihara oleh bank berupa SBI, SUN dan atau excess reserve terhadap dana pihak ketiga yang dimiliki bank (Rivai and Arifin 2013). Arifin $(2009,193)$ menyampaikan giro wajib minimum merupakan rasio antara saldo giro dari seluruh kantor bank yang tercatat pada Bank Indonesia setiap hari dengan rata-rata harian jumlah dana pihak ketiga (DPK) bank. Demikian halnya Yuniarti $(2018,196)$ mengungkapkan informasi DPK baru akan diketahui dua minggu kemudian, maka giro wajib minimum pada masa laporan berlaku dibandingkan dengan jumlah rata-rata harian DPK dari masa laporan sebelumnya. Simpanan minimum bank-bank umum dalam bentuk giro pada BI yang besarnya ditetapkan oleh BI berdasarkan persentase tertentu dari dana pihak ketiga. Giro wajib minimum adalah kewajiban bank untuk mendukung pelaksanaan prinsip kehati-hatian perbankan serta berperan sebagai instrumen moneter yang berfungsi mengendalikan jumlah peredaran uang (Yuniarti 2018, 196).

Besarnya GWM adalah 5\% dari dana pihak ketiga yang berbentuk IDR (rupiah) dan 3\% dari dana pihak ketiga yang berbentuk mata uang asing. Jumlah uang tersebut dihitung rata-rata harian dalam satu masa laporan untuk periode masa laporan sebelumnya. BI mengenakan denda terhadap kesalahan dan keterlambatan penyampaian laporan mingguan yang digunakan untuk menentukan GWM, bank yang melakukan pelanggaran juga terkena sanksi (Yuniarti 2018).

\section{Hubungan Antara Tingkat Inflasi Dengan Pembiayaan/Kredit}

Menurut pendapat Karim $(2017,210)$ hubungan inflasi dengan pembiayaan, bahwa tingkat inflasi yang naik turun di Indonesia menyebabkan perekonomian Indonesia tidak stabil, sehingga mengurangi pendapatan masyarakat. Berkurangnya pendapatan masyarakat ini mengakibatkan menurunnya jumlah nasabah penabung maupun jumlah nasabah pembiayaan sehingga secara tidak langsung mengakibatkan turunnya jumlah pembiayaan atau kredit. Penelitian yang dilakukan oleh Ali and Miftahurrohman (2016) menyatakan bahwa tingkat inflasi berpengaruh terhadap pembiayaan murabahah, maka dari itu dapat dirumuskan hipotesis sebagai berikut:

$\mathrm{H}_{1 \mathrm{a}}$ : tingkat inflasi berpengaruh terhadap kredit pada Bank Mandiri.

$\mathrm{H}_{1 \mathrm{~b}}$ : tingkat inflasi berpengaruh terhadap pembiayaan pada Bank Syariah Mandiri.

\section{Hubungan Antara BI 7-Day Repo Rate Dengan Pembiayaan/Kredit}

Hasoloan $(2014,65)$ mengungkapkan suku bunga acuan yang digunakan adalah BI Rate. Suku bunga sendiri didefiniskan sebagai pembayaran bunga tahunan dari suatu pinjaman, dalam bentuk presentase sebagai pembayaran bunga tahunan dari suatu pinjaman, dalam bentuk presentase dari pinjaman yang diperoleh dari jumlah bunga yang diterima tiap tahun dibagi dengan jumlah pinjaman. Penelitian yang dilakukan oleh Ali and Miftahurrohman (2016); Naufal, Fadilah, and Helliana (2017) menyatakan bahwa BI 7-day repo rate berpengaruh negatif terhadap pembiayaan, maka dari itu dapat dirumuskan hipotesis sebagai berikut:

$\mathrm{H}_{2 \mathrm{a}}$ : BI 7-day repo rate berpengaruh terhadap kredit pada Bank Mandiri.

$\mathrm{H}_{2 \mathrm{~b}}$ : BI 7-day repo rate berpengaruh terhadap pembiayaan pada Bank Syariah Mandiri. 


\section{Hubungan Antara Dana Pihak Ketiga Dengan Pembiayaan/Kredit}

Hubungan antara dana pihak ketiga dengan pembiayaan dalam konsep manajemen kredit atau pembiayaan, dana pihak ketiga merupakan kebijakan bank (Ichsan 2013). Penelitian yang dilakukan oleh Ali and Miftahurrohman (2016); Anwar and Miqdad (2017); Bakti (2017); Fitri, Maulida, and Indrawati (2017); Husaeni (2017) menyatakan bahwa dana pihak ketiga berpengaruh positif dan signifikan terhadap pembiayaan atau kredit, maka dari itu dapat dirumuskan hipotesis sebagai berikut:

$\mathrm{H}_{3 \mathrm{a}}$ : dana pihak ketiga berpengaruh terhadap kredit pada Bank Mandiri.

$\mathrm{H}_{3 \mathrm{~b}}$ : dana pihak ketiga berpengaruh terhadap pembiayaan pada Bank Syariah Mandiri.

\section{Hubungan Antara Giro Wajib Minimum Dengan Pembiayaan/Kredit}

Peraturan Bank Indonesia nomor 10/19/PBI/2008 tentang giro wajib minimum Bank Umum pada Bank Indonesia dalam valuta rupiah dan valuta asing. Namun tidak berselang lama, Bank Indonesia juga menerbitkan perubahan Peraturan Bank Indonesia nomor 10/19/PBI/2008 melalui Peraturan Bank Indonesia No. 10/25/PBI/2008 (Hermanto and Agung 2008). Penelitian yang dilakukan oleh Fitri, Maulida, and Indrawati (2017) menyatakan bahwa giro wajib minimum tidak berpengaruh terhadap penyaluran kredit, maka dari itu dapat dirumuskan hipotesis sebagai berikut:

$\mathrm{H}_{4 \mathrm{a}}$ : giro wajib minimum tidak berpengaruh terhadap kredit pada Bank Mandiri. $\mathrm{H}_{4 b}$ : giro wajib minimum tidak berpengaruh terhadap pembiayaan pada Bank Syariah Mandiri.

Berdasarkan teori-teori dan hasil penelitian yang ada mengenai pembiayaan perbankan maka dapat dirumuskan hipotesis sebagai berikut:

$\mathrm{H}_{5}$ : terdapat perbedaan pembiayaan antara Bank Mandiri dengan Bank Syariah Mandiri.

\section{METODE PENELITIAN}

Penelitian ini menggunakan pendekatan kuantitaif dengan jenis komparatif asosiatif. Pengumpulan data menggunakan instrumen penelitian yang bersifat membandingkan keberadaan satu variabel atau lebih pada dua atau lebih sampel yang berbeda. Populasi dalam penelitian ini adalah keseluruhan dari subjek penelitian yaitu Bank Mandiri dan Bank Syariah Mandiri yang ada di Indonesia. Penelitian ini menggunakan teknik pusposive sampling dengan kriteria, data yang digunakan berupa tingkat inflasi, BI 7-day repo rate, dana pihak ketiga dan giro wajib minimum Bank Mandiri dan Bank Syariah Mandiri periode 2012-2019. Data yang digunakan adalah data sekunder berupa dokumentasi dan kepustakaan. Dokumentasi berasal dari laporan keuangan Bank Indonesia dan situs resmi Bank Mandiri dan Bank Syariah Mandiri. Laporan keuangan yang digunakan adalah laporan keuangan triwulan periode 2012-2019 pada Bank Mandiri dan Bank Syariah Mandiri. Sedangkan kepustakaan berasal dari referensi melalui buku dan jurnal. Analisis data yang digunakan adalah analisis kuantitatif, pengujian menggunakan uji hipotesis dan independent sample test serta dibantu dengan program SPSS. 


\section{HASIL DAN PEMBAHASAN PENELITIAN}

\section{Data Deskriptif}

Tabel 1. Tingkat Inflasi 2012-2019 (persen)

\begin{tabular}{lcccccccc}
\hline \multicolumn{1}{c}{ Periode } & $\mathbf{2 0 1 2}$ & $\mathbf{2 0 1 3}$ & $\mathbf{2 0 1 4}$ & $\mathbf{2 0 1 5}$ & $\mathbf{2 0 1 6}$ & $\mathbf{2 0 1 7}$ & $\mathbf{2 0 1 8}$ & $\mathbf{2 0 1 9}$ \\
\hline Triwulan I & 3,97 & 5,90 & 7,32 & 8,36 & 4,45 & 3,40 & 3,40 & 2,48 \\
Triwulan II & 4,53 & 5,90 & 6,70 & 7,26 & 3,45 & 3,12 & 3,12 & 3,28 \\
Triwulan III & 4,13 & 8,40 & 4,53 & 6,83 & 3,07 & 2,88 & 2,88 & 3,39 \\
Triwulan IV & 4,30 & 8,38 & 8,36 & 3,35 & 3,02 & 3,13 & 3,13 & 2,72 \\
\hline
\end{tabular}

Sumber: data sekunder (diolah)

Pada Tabel 1, dapat diketahui bahwa nilai tingkat inflasi dari tahun 2012 sampai 2019 pertumbuhannya bergerak secara fluktuatif. Untuk tingkat inflasi tertinggi pada tahun 2013 Triwulan III sebesar 8,40\% dan nilai terendah pada tahun 2019 Triwulan I sebesar 2,48\%. Menurut tingkatnya inflasi dibagi menjadi apabila angka inflasi 0\%-2,5\% menandakan kondisi perekonomian stabil. Saat angka inflasi 2,5\%-5\% menandakan tingkat inflasi sedang. Angka inflasi 5\%-8\% menandakan inflasi tinggi.

Tabel 2. BI 7-Day Repo Rate 2012-2019 (persen)

\begin{tabular}{lcccccccc}
\hline \multicolumn{1}{c}{ Periode } & $\mathbf{2 0 1 2}$ & $\mathbf{2 0 1 3}$ & $\mathbf{2 0 1 4}$ & $\mathbf{2 0 1 5}$ & $\mathbf{2 0 1 6}$ & $\mathbf{2 0 1 7}$ & $\mathbf{2 0 1 8}$ & $\mathbf{2 0 1 9}$ \\
\hline Triwulan I & 5,75 & 5,75 & 7,50 & 6,38 & 4,45 & 3,40 & 3,40 & 6,00 \\
Triwulan II & 5,75 & 6,00 & 6,70 & 7,26 & 3,45 & 3,12 & 3,12 & 6,00 \\
Triwulan III & 5,75 & 5,75 & 4,53 & 7,26 & 3,07 & 3,12 & 2,88 & 5,25 \\
Triwulan IV & 5,75 & 7,50 & 7,75 & 7,50 & 4,75 & 3,13 & 3,13 & 5,00 \\
\hline Sumber: data sekunder (diolah) & & & & & &
\end{tabular}

Sumber: data sekunder (diolah)

Berdasarkan Tabel 2, dapat dilihat bahwa sejak tahun 2012 masih mengggunakan acuan BI Rate dengan persentasenya pada triwulan I terendah sebesar 5,75\% sehingga sejak tahun 2018 sudah menjadi acuan BI 7-day repo rate diresmikan sebagai bunga acuan baru, persentasenya terus mengalami penurunan secara fluktuatif hingga bulan desember 2019. Hal ini ditunjukkan agar BI 7-day repo rate dapat mempengaruhi pasar uang dan perbankan.

Tabel 3. Dana Pihak Ketiga Bank Mandiri 2012-2019 (triliun rupiah)

\begin{tabular}{lcccccccc}
\hline \multicolumn{1}{c}{ Periode } & $\mathbf{2 0 1 2}$ & $\mathbf{2 0 1 3}$ & $\mathbf{2 0 1 4}$ & $\mathbf{2 0 1 5}$ & $\mathbf{2 0 1 6}$ & $\mathbf{2 0 1 7}$ & $\mathbf{2 0 1 8}$ & $\mathbf{2 0 1 9}$ \\
\hline Triwulan I & 360,731 & 418,678 & 167,622 & 225,129 & 213,917 & 224,411 & 222,579 & 684,530 \\
Triwulan II & 375,043 & 451,275 & 181,045 & 220,111 & 217,636 & 228,925 & 671,171 & 725,293 \\
Triwulan III & 386,334 & 459,940 & 198,224 & 207,595 & 216,629 & 225,581 & 244,633 & 728,293 \\
Triwulan IV & 435,458 & 499,718 & 223,828 & 200,431 & 233,617 & 203,860 & 247,286 & 0 \\
\hline \multicolumn{5}{l}{ Sumber: data sekunder(diolah) }
\end{tabular}

Tabel 4. Dana Pihak Ketiga Bank Syariah Mandiri 2012-2019 (juta rupiah)

\begin{tabular}{lcccccccc}
\hline \multicolumn{1}{c}{ Periode } & $\mathbf{2 0 1 2}$ & $\mathbf{2 0 1 3}$ & $\mathbf{2 0 1 4}$ & $\mathbf{2 0 1 5}$ & $\mathbf{2 0 1 6}$ & $\mathbf{2 0 1 7}$ & $\mathbf{2 0 1 8}$ & $\mathbf{2 0 1 9}$ \\
\hline Triwulan I & $8.147,68$ & $7.767,15$ & $51.366,2$ & $55.484,1$ & $63.160,2$ & $71.035,5$ & $82.584,1$ & $87.154,7$ \\
Triwulan II & $7.986,58$ & $10.072,3$ & $51.597,6$ & $59.164,4$ & $63.792,1$ & $72.327,3$ & $82.416,5$ & $87.354,8$ \\
Triwulan III & $9.432,95$ & $11.777,4$ & $53.249,6$ & $59.707,7$ & $65.977,5$ & $74.750,5$ & $82.275,4$ & $90.494,3$ \\
Triwulan IV & $11.449,3$ & $14.384,1$ & $55.156,6$ & $62.112,8$ & $69.949,8$ & $77.903,1$ & $87.471,8$ & 0 \\
\hline \multicolumn{5}{l}{ Sumber: data sekunder(diolah) }
\end{tabular}


Berdasarkan Tabel 3, dapat dilihat bahwa selama tahun 2012-2019 dana pihak ketiga Bank Mandiri cenderung naik turun dari tahun ke tahunnya. Nilai dana pihak ketiga terendah selama kurun 8 tahun terjadi pada tahun 2016 Triwulan I sebesar 167,622 triliun rupiah. Sedangkan dana pihak ketiga tertinggi yang pernah dihimpun di Bank Mandiri pada tahun Triwulan III pada tahun 2019 sebesar 728,122 triliun rupiah. Demikian halnya pada Tabel 4, jumlah dana pihak ketiga Bank Syariah Mandiri dapat dilihat bahwa selama tahun 2012-2019 mengalami fluktuatif dari tahun ke tahun, disebabkan karena dana pihak ketiga Bank Syariah Mandiri mengalami pengaruh pada pembiayaan yang semakin tinggi maka simpanan nasabah seperti halnya tabungan ,deposito, giro mengalami kenaikan sehingga nasabah lebih memilih pola saving dan nasabah menanamkan dananya. Berdasarkan data Triwulan I Tahun 2013 dana pihak ketiga terendah sebesar 7.767,15 juta rupiah, sedangkan dana pihak ketiga yang tertinggi pada tahun 2019 triwulan III sebesar 90.494 juta rupiah.

Tabel 5. Giro Wajib Minimum Bank Mandiri 2012-2019 (persen)

\begin{tabular}{lcccccccc}
\hline \multicolumn{1}{c}{ Periode } & $\mathbf{2 0 1 2}$ & $\mathbf{2 0 1 3}$ & $\mathbf{2 0 1 4}$ & $\mathbf{2 0 1 5}$ & $\mathbf{2 0 1 6}$ & $\mathbf{2 0 1 7}$ & $\mathbf{2 0 1 8}$ & $\mathbf{2 0 1 9}$ \\
\hline Triwulan I & 8,00 & 8,00 & 8,10 & 8,00 & 6,50 & 6,78 & 6,69 & 6,05 \\
Triwulan II & 8,00 & 8,00 & 8,10 & 8,00 & 6,50 & 6,78 & 6,69 & 6,05 \\
Triwulan III & 8,00 & 8,00 & 8,10 & 8,00 & 6,50 & 6,78 & 6,69 & 6,05 \\
Triwulan IV & 8,00 & 8,00 & 8,00 & 7,50 & 6,50 & 6,78 & 6,69 & - \\
\hline \multicolumn{7}{l}{ Sumber: data sekunder (diolah) }
\end{tabular}

Tabel 6. Giro Wajib Minimum Bank Syariah Mandiri 2012-2019 (persen)

\begin{tabular}{lcccccccc}
\hline \multicolumn{1}{c}{ Periode } & $\mathbf{2 0 1 2}$ & $\mathbf{2 0 1 3}$ & $\mathbf{2 0 1 4}$ & $\mathbf{2 0 1 5}$ & $\mathbf{2 0 1 6}$ & $\mathbf{2 0 1 7}$ & $\mathbf{2 0 1 8}$ & $\mathbf{2 0 1 9}$ \\
\hline Triwulan I & 5,07 & 5,06 & 5,05 & 5,05 & 5,09 & 8,12 & 8,4 & 5,24 \\
Triwulan II & 5,07 & 5,06 & 5,05 & 5,05 & 5,09 & 5,12 & 5,05 & 5,04 \\
Triwulan III & 5,06 & 5,20 & 5,05 & 5,05 & 5,14 & 5,13 & 5,04 & 4,54 \\
Triwulan IV & 5,06 & 5,20 & 5,05 & 5,09 & 5,14 & 8,05 & 5,05 & - \\
\hline
\end{tabular}

Sumber: data sekunder (diolah)

Berdasarkan Tabel 5, dapat dilihat bahwa giro wajib minimum Bank Mandiri selama tahun 2012-2019 mengalami kecenderungan fluktuatif dari tahun ke tahunnya. Nilai giro wajib minimum terendah terjadi pada tahun 2019 triwulan I, II dan III sebesar 6,05\%. Sedangkan nilai tertinggi tertinggi pada tahun 2012 dan 2013 sebesar 8,00\%. Pada Tabel 6, dapat dilihat bahwa giro wajib minimum Bank Syariah Mandiri selama tahun 2012-2019 mengalami fluktuatif dari tahun ke tahun. Nilai giro wajib minimum terendah terjadi pada tahun 2019 triwulan III sebesar $4,54 \%$. Sedangkan nilai giro wajib minimum tertinggi terjadi pada tahun 2019 Triwulan I sebesar 8,12\%.

Tabel 7. Kredit Bank Mandiri 2012-2019 (triliun rupiah)

\begin{tabular}{lcccccccc}
\hline \multicolumn{1}{c}{ Periode } & $\mathbf{2 0 1 2}$ & $\mathbf{2 0 1 3}$ & $\mathbf{2 0 1 4}$ & $\mathbf{2 0 1 5}$ & $\mathbf{2 0 1 6}$ & $\mathbf{2 0 1 7}$ & $\mathbf{2 0 1 8}$ & $\mathbf{2 0 1 9}$ \\
\hline Triwulan I & 286,259 & 340,654 & 475,266 & 478,519 & 513,809 & 585,052 & 614,632 & 684,530 \\
Triwulan II & 306,832 & 375,203 & 430,384 & 495,767 & 546,952 & 605,622 & 235,478 & 725,293 \\
Triwulan III & 319,154 & 395,830 & 451,841 & 502,779 & 560,320 & 605,885 & 684,657 & 728,122 \\
Triwulan IV & 339,973 & 416,978 & 475,266 & 536,029 & 592,669 & 644,257 & 718,966 & 0 \\
\hline
\end{tabular}

Sumber: data sekunder (diolah) 
Tabel 8. Pembiayaan Bank Syariah Mandiri 2012-2019 (juta rupiah)

\begin{tabular}{lcccccccc}
\hline \multicolumn{1}{c}{ Periode } & $\mathbf{2 0 1 2}$ & $\mathbf{2 0 1 3}$ & $\mathbf{2 0 1 4}$ & $\mathbf{2 0 1 5}$ & $\mathbf{2 0 1 6}$ & $\mathbf{2 0 1 7}$ & $\mathbf{2 0 1 8}$ & $\mathbf{2 0 1 9}$ \\
\hline Triwulan I & $2.431,5$ & $1.276,4$ & 10.126 & $9.684,9$ & 14.677 & 17.144 & 21.733 & 26.948 \\
Triwulan II & $2.185,2$ & $1.149,7$ & $9.964,9$ & 10.323 & 15.731 & 19.850 & 22.517 & 27.479 \\
Triwulan III & $2.231,7$ & $1.346,9$ & 10.323 & 13.758 & 15.762 & 20.550 & 24.658 & 28.462 \\
Triwulan IV & $2.112,4$ & $1.695,4$ & $9.992,6$ & 14.677 & 17.397 & 21.826 & 25.329 & 0 \\
\hline
\end{tabular}

Sumber: data sekunder (diolah)

Berdasarkan Tabel 7, dapat dilihat bahwa kredit Bank Mandiri selama tahun 2012-2019 mengalami kecenderungan fluktuatif dari tahun ke tahunnya. Nilai kredit terendah terjadi pada tahun 2012 Triwulan II sebesar 235,478 triliun rupiah. Nilai kredit tertinggi pada tahun 2019 Triwulan III sebesar 728,122 triliun rupiah. Berdasarkan Tabel 8, dapat dilihat bahwa pembiayaan Bank Syariah Mandiri selama tahun 2012-2019 mengalami kecenderungan fluktuatif dari tahun ke tahunnya. Nilai pembiayaan terendah terjadi pada tahun 2012 Triwulan IV sebesar 2.112,4 jutaan rupiah. Sedangkan nilai pembiayaan tertinggi terjadi pada tahun 2019 triwulan III sebesar 28.462 jutaan rupiah.

\section{Uji Hipotesis}

Uji hipotesis dapat digunakan untuk mengetahui pengaruh parsial dari masing-masing variabel bebas yang ada terhadap variabel terikat dalam penelitian. Uji $t$ dapat dilakukan dengan membandingkan nilai $t_{\text {hitung }}$ dengan $t_{\text {tabel }}$ dengan tingkat kesalahan $(\alpha)=0,05$. Dalam pengambilan keputusan pada uji $\mathrm{t}$, apabila $t_{\text {hitung }}>t_{\text {tabel }}$ dan sig. $<0,05$ maka terdapat pengaruh signifikan variabel bebas terhadap variabel terikat, apabila $\mathrm{t}_{\text {hitung }}<\mathrm{t}_{\text {tabel }}$ dan sig. $>0,05$ maka tidak terdapat pengaruh dan tidak signifikan variabel bebas terhadap variabel terikat. Pada uji hipotesis ini didapat nilai $t_{\text {tabel }}$ sebesar 1,976.

\begin{tabular}{lcccccc} 
& \multicolumn{2}{c}{$\begin{array}{c}\text { Tabel 9. Hasil Uji t Bank Mandiri } \\
\text { Vnstandardized }\end{array}$} & $\begin{array}{c}\text { Standardized } \\
\text { Variable }\end{array}$ & $\begin{array}{c}\text { Coefficients } \\
\text { Coefficients }\end{array}$ & \multirow{2}{*}{ T } & \multirow{2}{*}{ Sig. } \\
\cline { 2 - 5 } & $\boldsymbol{B}$ & Std. Error & Beta & & \\
\hline Tingkat Inflasi & 0,001 & 0,028 & 0,009 & 0,052 & 0,959 \\
BI 7-Day Repo Rate & 0,036 & 0,036 & 0,148 & 0,995 & 0,329 \\
Dana Pihak Ketiga & 0,621 & 0,118 & 0,928 & 5,283 & 0,000 \\
Giro Wajib Minimum & 0,009 & 0,065 & 0,028 & 0,143 & 0,888 \\
\hline
\end{tabular}

Sumber: data sekunder (diolah)

Tabel 10. Hasil Uji t Bank Syariah Mandiri

\begin{tabular}{lcccccc}
\hline \multirow{1}{*}{\multicolumn{1}{c}{ Variabel }} & \multicolumn{2}{c}{$\begin{array}{c}\text { Unstandardized } \\
\text { Coefficients }\end{array}$} & $\begin{array}{c}\text { Standardized } \\
\text { Coefficients }\end{array}$ & \multirow{T}{*}{$\boldsymbol{T}$} & \multirow{2}{*}{ Sig. } \\
\cline { 2 - 5 } & $\boldsymbol{B}$ & Std. Error & Beta & & \\
\hline Tingkat Inflasi & $-0,159$ & 0,062 & $-0,285$ & $-2,564$ & 0,016 \\
BI 7-Day Repo Rate & 0,065 & 0,095 & 0,074 & 0,682 & 0,501 \\
Dana Pihak Ketiga & 0,856 & 0,100 & 0,783 & 8,537 & 0,000 \\
Giro Wajib Minimum & 0,046 & 0,108 & 0,039 & 0,425 & 0,674 \\
\hline
\end{tabular}

Sumber: data sekunder (diolah) 
Berdasarkan Tabel 9, dapat dilihat variabel inflasi memiliki nilai $\mathrm{t}_{\text {hitung }}$ sebesar $0,052<\mathrm{t}_{\text {tabel }} 1,976$ dan sig. sebesar 0,959>0,05 berarti tingkat inflasi tidak memiliki pengaruh dan tidak signifikan terhadap kredit pada Bank Mandiri $\left(\mathrm{H}_{1 \mathrm{a}}\right.$ ditolak). Variabel BI 7-day repo rate memiliki nilai $\mathrm{t}_{\text {hitung }}$ sebesar $0,995<$ $\mathrm{t}_{\text {tabel }}$ 1,976 dan sig. sebesar 0,329>0,05 berarti BI 7-day repo rate tidak memiliki pengaruh dan tidak signifikan terhadap kredit pada Bank Mandiri $\left(\mathrm{H}_{2 \mathrm{a}}\right.$ ditolak). Variabel dana pihak ketiga memiliki nilai $t_{\text {hitung }}$ sebesar 5,283 $>t_{\text {tabel }}$ 1,976 dan sig. sebesar $0,000<0,05$ berarti dana pihak ketiga berpengaruh dan signifikan terhadap kredit pada Bank Mandiri $\left(\mathrm{H}_{3 \mathrm{a}}\right.$ diterima). Variabel giro wajib minimum memiliki nilai $t_{\text {hitung }}$ sebesar $0,143<\mathrm{t}_{\text {tabel }} 1,976$ dan sig. sebesar 0,888 $>0,05$ berarti giro wajib minimum tidak memiliki pengaruh dan tidak signifikan terhadap kredit pada Bank Mandiri $\left(\mathrm{H}_{4 \mathrm{a}}\right.$ diterima).

Berdasarkan Tabel 10, dapat dilihat variabel inflasi memiliki nilai $t_{\text {hitung }}$ sebesar $-2,564<\mathrm{t}_{\text {tabel }} 1,976$ dan sig. sebesar $0,016<0,05$ berarti tingkat inflasi tidak memiliki pengaruh dan signifikan terhadap pembiayaan pada Bank Syariah Mandiri $\left(\mathrm{H}_{1 \mathrm{~b}}\right.$ ditolak). Variabel BI 7-day repo rate memiliki nilai $\mathrm{t}_{\text {hitung }}$ sebesar $0,682<\mathrm{t}_{\text {tabel }} 1,976$ dan sig. sebesar 0,501 >0,05 berarti BI 7-day repo rate tidak memiliki pengaruh dan tidak signifikan terhadap pembiayaan pada Bank Syariah Mandiri $\left(\mathrm{H}_{2 \mathrm{~b}}\right.$ ditolak). Variabel dana pihak ketiga memiliki nilai $\mathrm{t}_{\text {hitung }}$ sebesar 8,537 $>\mathrm{t}_{\text {tabel }} 1,976$ dan sig. sebesar $0,000<0,05$ berarti dana pihak ketiga berpengaruh dan signifikan terhadap pembiayaan pada Bank Syariah Mandiri $\left(\mathrm{H}_{3 b}\right.$ diterima). Variabel giro wajib minimum memiliki nilai $t_{\text {hitung }}$ sebesar $0,425<t_{\text {tabel }} 1,976$ dan sig. sebesar 0,674>0,05 berarti giro wajib minimum tidak memiliki pengaruh dan tidak signifikan terhadap pembiayaan pada Bank Syariah Mandiri $\left(\mathrm{H}_{4 \mathrm{~b}}\right.$ diterima).

\section{Komparatif Dua Sampel Bebas}

Analisis komparatif atau analisis perbedaan adalah salah satu analisis yang digunakan untuk mengetahui perbedaan antara dua variabel (data) atau lebih. Salah satu jenis uji perbedaan dua parameter rata-rata adalah analisis perbedaan dua parameter rata-rata sampel bebas (independent sample t-test). Sampel bebas diartikan sebagai dua sampel yang tidak saling berkolerasi. Berdasarkan Tabel 11, dapat dilihat bahwa nilai Sig. (2-tailed) sebesar 0,000 lebih kecil dari taraf signifikan $(0,05)$ sehingga terdapat perbedaan pembiayaan antara Bank Mandiri dengan Bank Syariah Mandiri ( $\mathrm{H}_{5}$ diterima).

Tabel 11 Uji Independent Sample T-Test Bank Mandiri Dan Bank Syariah Mandiri

\begin{tabular}{lccccccc}
\hline Variable & $\boldsymbol{F}$ & Sig. & $\boldsymbol{t}$ & $\boldsymbol{d f}$ & $\begin{array}{c}\text { Sig. } \\
(2-\text {-tailed) }\end{array}$ & $\begin{array}{c}\text { Mean } \\
\text { Difference }\end{array}$ & $\begin{array}{c}\text { Std. Error } \\
\text { Difference }\end{array}$ \\
\hline Pembiayaan & 59,860 & 0,000 & 19,719 & 60 & 0,000 & 491,90323 & 24,94610 \\
\hline Sumber: data sekunder (diolah) & & & & &
\end{tabular}

\section{Pengaruh Tingkat Inflasi Terhadap Pembiayaan/Kredit}

Berdasarkan hasil pengujian dapat diketahui bahwa $\mathrm{H}_{1 \mathrm{a}}$ ditolak dan $\mathrm{H}_{1 \mathrm{~b}}$ ditolak, ini berarti tingkat inflasi tidak berpengaruh dan tidak signifikan terhadap kredit atau pembiayaan pada Bank Mandiri dan Bank Syariah Mandiri. Hal tersebut menggambarkan bahwa inflasi yang terjadi dalam suatu negara tidak selamanya mempengaruhi rasio keuangan di dunia perbankan khususnya kredit 
atau pembiayaan. Hal ini terjadi karena setiap negara pasti mempunyai suatu kebijakan tertentu untuk menjaga perekonomian agar tidak berada pada posisi inflasi, dengan adanya kebijakan tersebut nantinya membuat perekonomian suatu negara stabil dan tidak berimbas pada rasio keuangan bank konvensional maupun syariah. Selain itu setiap bank pastinya juga mempunyai suatu kebijakan atau cara tersendiri untuk mengatasi inflasi, sehingga jika sewaktu-waktu terjadi inflasi maka akan tidak secara langsung berimbas pada dunia perbankan.

Hasil penelitian ini sejalan dengan penelitian yang dilakukan oleh Dahlan (2014) yang menunjukkan bahwa inflasi tidak berpengaruh dan tidak signifikan terhadap penyaluran pembiayaan pada Bank Syariah di Indonesia. Hasil penelitian ini bertolak belakang dengan penelitian yang telah dilakukan oleh Ali and Miftahurrohman (2016); Naufal, Fadilah, and Helliana (2017) yang menyatakan bahwa inflasi berpengaruh terhadap pembiayaan. Ali and Miftahurrohman (2016) menyatakan bahwa pengaruh inflasi terhadap pembiayaan signifikan, sedangkan Naufal, Fadilah, and Helliana (2017) tidak signifikan.

\section{Pengaruh BI 7-Day Repo Rate Terhadap Pembiayaan/Kredit}

Berdasarkan hasil pengujian dapat diketahui bahwa $\mathrm{H}_{2 \mathrm{a}}$ ditolak dan $\mathrm{H}_{2 \mathrm{~b}}$ ditolak, ini berarti BI 7-day repo rate tidak berpengaruh dan tidak signifikan terhadap kredit atau pembiayaan Bank Mandiri dan Bank Syariah Mandiri. Hal tersebut dikarenakan ketika BI 7-day repo rate naik masyarakat juga menjadi enggan untuk melakukan kredit atau pembiayaan karena bunga atau margin yang ditawarkan cukup tinggi. Disisi lain masyarakat lebih cenderung berbondongbondong untuk menyimpan uangnya karena tingkat bunga atau bagi hasil lebih besar. Hasil penelitian ini bertolak belakang dengan penelitian yang dilakukan oleh Ali and Miftahurrohman (2016); Naufal, Fadilah, and Helliana (2017) yang menyatakan bahwa BI 7- Day Repo Rate berpengaruh terhadap pembiayaan.

\section{Pengaruh Dana Pihak Ketiga Terhadap Pembiayaan/Kredit}

Berdasarkan hasil pengujian dapat diketahui bahwa $\mathrm{H}_{3 \mathrm{a}}$ diterima dan $\mathrm{H}_{3 \mathrm{~b}}$ diterima, ini berarti dana pihak ketiga berpengaruh dan signifikan terhadap kredit atau pembiayaan Bank Mandiri dan Bank Syariah Mandiri. Hal ini terindikasi jika jumlah dana pihak ketiga dalam suatu perbankan tinggi, maka peluang untuk diputarkan kepembiayaan juga semakin tinggi dan jumlah laba yang dihasilkan semakin besar. Sebalikanya jika jumlah dana pihak ketiga rendah maka peluang disalurkan kepembiayaan juga rendah.

Penelitian ini sejalan dengan penelitian yang dilakukan oleh Ali and Miftahurrohman (2016); Anwar and Miqdad (2017); Bakti (2017); Fitri, Maulida, and Indrawati (2017); Husaeni (2017) menyatakan bahwa dana pihak ketiga berpengaruh positif dan signifikan terhadap kredit atau pembiayaan. Kemudian hasil penelitian ini juga diperkuat oleh Olokoyo (2011) yang menyatakan bahwa deposito bank komersial memiliki dampak besar terhadap penyaluran pinjaman.

\section{Pengaruh Giro Wajib Minimum Terhadap Pembiayaan/Kredit}

Berdasarkan hasil pengujian dapat diketahui bahwa $\mathrm{H}_{4 a}$ diterima dan $\mathrm{H}_{4 b}$ diterima, ini berarti giro wajib minimum tidak berpengaruh dan tidak signifikan terhadap kredit atau pembiayaan pada Bank Mandiri dan Bank Syariah Mandiri. Hal tersebut terjadi karena apabila bank sentral melaksanakan kebijakan moneter 
kontraktif, misalnya melalui peningkatan cadangan minimum di bank sentral, cadangan yang ada di bank akan mengalami penurunan sehingga dana yang dapat disalurkan dalam kredit atau pembiayaan oleh bank akan mengalami penurunan. Kemudian akan berdampak pada profitabilitas bank syariah, karena jika terlalu banyak dana yang disimpan dalam giro wajib minimum maka dana yang dapat disalurkan untuk pembiayaan akan berkurang. Hasil penelitian ini sejalan dengan penelitian yang dilakukan oleh Fitri, Maulida and Indrawati (2017) yang menyatakan bahwa giro wajib minimum tidak berpengaruh dan tidak signifikan terhadap penyaluran kredit pada PT. Bank Central Asia.

\section{Perbedaan Pembiayaan Pada Bank Mandiri Dengan Bank Syariah Mandiri}

Berdasarkan hasil uji independent sample t-test data pembiayaan Bank Mandiri dan Bank Syariah Mandiri menunjukkan bahwa $\mathrm{H}_{5}$ diterima, ini berarti terdapat perbedaan signifikan antara pembiayaan padad Bank Mandiri dan Bank Syariah Mandiri. Hal tersebut ditunjukkan dengan nilai Sig. (2-tailed) lebih kecil dari taraf signifikan. Kemudian perbedaan pembiayaan ini terjadi karena beberapa alasan seperti prosedur operasional dan acuan yang berbeda antara Bank Mandiri dan Bank Syariah Mandiri. Bank Mandiri menggunakan acuan suku bunga yang dipengaruhi oleh Bank Indonesia, sedangkan Bank Syariah Mandiri menggunakan sistem bagi hasil. Selanjutnya jumlah kantor pelayanan antara Bank Mandiri dan Bank Syariah Mandiri berbeda jauh, ini juga bisa menjadi pengaruh besarnya pembiayaan diantara dua lembaga tersebut. Tidak bisa dipungkiri bahwa jumlah Bank Mandiri saat ini lebih banyak dan lebih dikenal oleh masyarakat jika dibandingkan Bank Syariah Mandiri. Kondisi ini secara tidak langsung akan berefek pada jumlah aset yang dimiliki oleh kedua bank tersebut, sehingga terjadi perbedaan yang signifikan.

\section{KESIMPULAN}

Ternyata tingkat inflasi sama-sama tidak berpengaruh terhadap kredit atau pembiayaan pada Bank Mandiri dan Bank Syariah Mandiri. BI 7-day repo rate sama-sama tidak berpengaruh negatif terhadap kredit atau pembiayaan pada Bank Mandiri dan Bank Syariah Mandiri. Dana pihak ketiga sama-sama berpengaruh dan siginifikan terhadap kredit atau pembiayaan pada Bank Mandiri dan Bank Syariah Mandiri. Giro wajib minimum sama-sama tidak berpengaruh terhadap kredit atau pembiayaan pada Bank Mandiri dan Bank Syariah Mandiri. Kemudian terdapat perbedaan yang signifikan antara pembiayaan antara Bank Mandiri dan Bank Syariah Mandiri.

Hasil penelitian ini dapat memberikan masukan bagi pihak perbankan syariah, khususnya Bank Syariah Mandiri. Bahwa dalam menentukan kebijakan pembiayaan perlu diperhatikan faktor-faktor yang mempengaruhi dalam pembiayaan, baik itu faktor internal maupun faktor eksternalnya, sehingga dapat meningkatkan pembiayaan. Penelitian ini memiliki keterbatasan dalam jumlah variabel dan subjek penelitian.

Bagi perbankan syariah terutama Bank Syariah Mandiri diharapkan lebih meningkatkan pembiayaan di masa yang akan datang. Sedangkan bagi penelitian lanjutan disarankan untuk menambah variabel makro ekonomi seperti PDB, Nilai tukar dan variabel yang berasal dari faktor internal bank seperti rasio-rasio 
keungan lainnya yang berpengaruh terhadap pembiayaan. Kemudian penelitian lanjutan dapat menambah subjek penelitian dari Bank Umum Syariah, Bank Perkreditan Rakyat Syariah dan Unit-Unit Syariah.

\section{DAFTAR PUSTAKA}

Ali, Herni, and Miftahurrohman Miftahurrohman. 2016. "Determinan Yang Mempengaruhi Pembiayaan Murabahah Pada Perbankan Syariah Di Indonesia". Esensi: Jurnal Bisnis dan Manajemen, 6 (1): 31-44. http://journal.uinjkt.ac.id/index.php/esensi/article/view/3119.

Antonio, Muhammad Syafii. 2005. Bank Syariah Dari Teori Ke Praktik.Jakarta: Gema Insani.

Anwar, Chairul, and Muhammad Miqdad. 2017. "Pengaruh Dana Pihak Ketiga (DPK), Capital Adequacy Ratio (CAR), Return On Asset (ROA) Terhadap Pembiayaan Mudharabah Pada Bank Umum Syariah Tahun 2008-2012, 1 (1): 42-47. http://owner.polgan.ac.id/index.php/owner/article/view/14.

Ascarya, Ascarya. 2008. Akad dan Produk Bank Syariah. Jakarta: PT Raja Grafindo Persada.

Arifin, Zainul. 2009. Dasar-DasarManajemen Bank Syariah. Jakarta: Azkia Publisher.

BI. 2020. BI-7 Day Reverse Repo Rate (BI7DRR). Jakarta: Bank Indonesia. https://www.bi.go.id/id/fungsi-utama/moneter/bi-7day-rr/default.aspx.

Bakti, Nurimansyah Setivia. 2017. "Analisis DPK, CAR, ROA dan NPF Terhadap Pembiayaan Pada Perbankan Syariah". Jurnal Bisnis dan Manajemen, 17 (2): 15-28. https://doi.org/10.20961/jbm.v17i2.17180.

Campbell, R. Mc. Connel dan Stanley L. Brue. 1990. Economics: Principles, Problems, and Policies. Mc. Graw: Hill Publishing.

Dahlan, Ahmad. 2012. Bank Syariah Teoritik, Praktik, Kritik. Yogyakarta: Teras.

Dahlan, Rahmat. 2014. "Pengaruh Tingkat Bonus Sertifikat Bank Indonesia Syariah Dan Tingkat Inflasi Terhadap Pembiayaan Bank Syariah Di Indonesia". Etikonomi: Jurnal Ekonomi, 13 (2): 104-117. http://dx.doi.org/10.15408/etk.v13i2.1881.

Fitri, Lailatul, Yusni Maulida, and Toti Indrawati. 2017. "Pengaruh Suku Bunga Kredit, Dana Pihak Ketiga (DPK), dan Giro Wajib Minimum Terhadap Penyaluran Kredit pada PT. Bank Central Asia, Tbk. Di Indonesia Tahun 2001-2015". Jurnal Online Mahasiswa Fakultas Ekonomi Universitas $\begin{array}{llll}\text { Riau, } & 4 & \text { 379-392. }\end{array}$ http://jom.unri.ac.id/index.php/JOMFEKON/article/view/12327.

Hasoloan, Jimmy. 2016. Ekonomi Moneter. Yogyakarta: Deepublish.

Hermanto, Bambang, and Mulyo Agung. 2015. Analisa Laporan Keuangan. Jakarta: Lentera Ilmu Cendekia.

Husaeni, Uus Ahmad. 2017. "Determinan Pembiayaan Pada Bank Pembiayaan Rakyat Syariah Di Indonesia". Esensi: Jurnal Bisnis dan Manajemen, 7 (1): 49-62. http://dx.doi.org/10.15408/ess.v7i1.4542.

Ichsan, Nurul. 2013. "Pengelolaan Likuiditas Bank Syariah". Al-Iqtishad: Jurnal $\begin{array}{lllll}\text { Ilmu Ekonomi } & \text { Syariah, } & 6 & \text { (1): }\end{array}$ http://dx.doi.org/10.15408/aiq.v6i1.1371. 
Karim, Adiwarman Azwar. 2004. Ekonomi Makro Islami. Jakarta: PT Grafindo Persada.

Karim, Adiwarman A. 2017. Ekonomi Makro Islam. Jakarata: Rajawali Pers.

Kasmir, Kasmir. 2005. Bank dan Lembaga Keuangan Lainnya. Jakarta: Raja Grafindo Persada.

Kasmir, Kasmir. 2016. Bank dan Lembaga Keuangan. Jakarta: PT. Raja Grafindo Persada.

Marimin, Agus, and Abdul Haris Romdhoni. 2015. "Perkembangan Bank Syariah di Indonesia". Jurnal Ilmiah Ekonomi Islam (JIEI), 1 (2): 75-87. http://dx.doi.org/10.29040/jiei.v1i02.30.

Muhamad, Muhamad. 2019. Manajemen Dana Bank Syariah. Depok: PT Raja Grafindo Persada.

Naufal, Tanesia, Sri Fadilah, and Helliana Helliana. 2017. Pengaruh Dana Pihak Ketiga, Rasio Keuangan Bank, Inflasi dan Bi Rate terhadap Volume Pembiayaan. Skripsi Program Studi Akuntansi Universitas Islam Bandung. http://repository.unisba.ac.id/handle/123456789/24740.

Olokoyo, Felicia Omowunmi. 2011. "Determinants of Commercial Banks' Lending Behavior in Nigeria". International Journal of Financial Research 2 (2): 61-72. https://doi.org/10.5430/ijfr.v2n2p61.

Puspopranoto, Sawaldjo. 2004. Keuangan Perbankan dan Pasar Keuangan konsep, teori dan realita. Jakarta: Pustaka LP3ES Indonesia.

Rivai, Veithzal, and Arviyan Arifin. 2013. Comercial Bank Management Manajemen Perbankan Dari Teori ke Praktik. Jakarta: Rajawali Pers.

Siamat, Dahlan. 2005. Manajemen Lembaga Keuangan: Kebijakan Moneter dan Perbankan. Jakarta: Sinar Grafika.

Yuniarti, Vinna Sri. 2018. Ekonomi Makro Syariah, Cetakan I. Bandung: CV. Pustaka Setia. 